\title{
CZY OJCOWIE KOŚCIOLA PRZED AUGUSTYNEM MÓWILI O GRZECHU PIERWORODNYM?
}

Nawet wśród teologów i patrologów istnieje głębokie przekonanie, że grzech pierworodny wymyślił Augustyn. Czy tak jest rzeczywiście? Oczywiście, w sferze werbalnej - tak. Augustyn rzeczywiście precyzyjnie nazwał to, o czym jednak mówiono od dawna i co stanowi prawdziwy punkt wyjścia chrześcijańskiej antropologii. Problem interpretacji wypowiedzi wcześniejszych od niego Ojców budzi mnóstwo kontrowersji. Strony okopały się na swoich pozycjach - jedna dopatruje się wzmianek o grzechu pierworodnym już w pierwszych pismach Ojców Apostolskich, druga udowadnia, że koncepcję tę wymyślił Augustyn w trakcie kontrowersji pelagiańskiej. Osobiście uważam, że żadna ze stron nie ma racji. Pierwsza próbuje na siłę włożyć w usta Ojców słowa, których nie mogli i nie chcieli wypowiedzieć, druga udaje, że nie widzi niesamowitego bogactwa nauczania Ojców, które wręcz roi się od tekstów o naszej solidarności z Adamem. Żeby stwierdzić, czy Ojcowie wcześniejsi zajmowali się problemem grzechu pierworodnego, przyjrzyjmy się przynajmniej niektórym ich wypowiedziom związanym $\mathrm{z}$ upadkiem Adama.

1. Ireneusz z Lyonu. Już u żyjącego w II wieku Ireneusza z Lyonu po raz pierwszy pojawia się stwierdzenie: „Obraziliśmy Boga w pierwszym Adamie (in primo Adam) przez niewypełnienie Jego przykazania" jako potwierdzenie ontycznej solidarności wszystkich ludzi z pierwszym rodzicem. Punktem wyjścia Ireneuszowej nauki o solidarności ludzkości z Adamem jest przekonanie o jedności wszystkich ludzi w Chrystusie. Zanegowanie jedności ludzi w Adamie i naszego uczestnictwa w jego grzechu i śmierci oznaczałoby zanegowanie naszej jedności w Chrystusie i naszego uczestnictwa w odkupieniu $^{2}$. Ireneusz widzi w Adamie typ Chrystusa, a w Chrystusie wypełnienie czynów Adama, dokonane na zasadzie antytezy, odwrócenia. Ta równowaga czy

\footnotetext{
* Dr Marta Przyszychowska - adiunkt w Katedrze Historii Średniowiecznej w Instytucie Nauk Historycznych na Wydziale Nauk Historycznych i Społecznych Uniwersytetu Kard. Stefana Wyszyńskiegow Warszawie; e-mail: mpsi@interia.pl.

${ }^{1}$ Irenaeus, Adversus haereses V 16, 3, ed. A. Rousseau - L. Doutreleau - Ch. Mercier, SCh 153, Paris 1969, 220, thum. własne.

${ }^{2}$ Por. H. Lassiat, Pour une théologie de l'homme: création - liberté - incorruptibilité. Insertion
} 
odpowiedniość zdarzeń wymaga, by nasze uczestnictwo w odkupieniu Chrystusa odpowiadało naszemu uczestnictwu w grzechu Adama. Doktryna rekapitulacji zakłada, że Chrystus jest sumą i reprezentantem odnowionej ludzkości, a analogia wymaga, by Adam był podobnie typem i całością ludzkości³

Dla Ireneusza termin „Adam” ma najczęściej znaczenie zbiorowe i oznacza człowieka lub ludzkość ${ }^{4}$. Adam jest jednocześnie pojmowany w sensie ogólnym - człowiek, i jednostkowym - ten człowiek. To podwójne znaczenie Adama pozwala Ireneuszowi przechodzić od perspektywy szczegółowej do ogólnej, od osoby do ludzkiej natury ${ }^{5}$. To podwójne znaczenie widać wyraźnie w poniższym tekście:

„A więc jak przez nieposłuszeństwo dziewicy człowiek upadł, a upadając umarł, tak przez dziewicę, która była posłuszna Słowu Bożemu, człowiek na powrót ożył i przyjął życie. Pan bowiem przyszedł szukać zagubionej owcy. A zagubił się człowiek. I dlatego nie powstało jakieś nowe stworzenie, ale rodząc się z tej, której ród był od Adama, zachował podobieństwo ukształtowania. Trzeba było bowiem zjednoczyć i zrekapitulować Adama w Chrystusa, aby to, co śmiertelne, wchłonięte zostało przez nieśmiertelność, a Ewę [zrekapitulować] przez Maryję, aby dziewica stała się orędowniczką dziewicy i usunęła dziewicze nieposłuszeństwo przez posłuszeństwo dziewicy. To zaś przekroczenie, które zostało popełnione przy pomocy drzewa, zostało usunięte przez posłuszeństwo, przez które posłuszny Bogu Syn Człowieczy przybity został gwoźdźmi do drzewa odrzucając poznanie zła, a wprowadzając poznanie dobra. Złem jest nieposłuszeństwo Bogu, dobrem zaś posłuszeństwo Bogu"6.

$\mathrm{Z}$ jednej strony Adam oznacza tu konkretnego człowieka, z drugiej zaś jest kimś więcej niż tylko jednostką, stanowi określenie człowieka w ogóle. Także w innych miejscach Ireneusz niemal zawsze mówi o człowieku w liczbie pojedynczej, tak jakby był tylko jeden człowiek, szczególnie gdy mówi o etapach zbawienia przewidzianych przez Boga. Nie jest to jedynie figura retoryczna, lecz odwołanie do żywej i organicznej jedności, którą tworzą wszyscy ludzie ${ }^{7}$.

Jeśli tak jest, jeśli ludzkość tworzy żywą jedność w Adamie, to Chrystus, włączając w siebie Adama, przez samo to włączył w siebie całą ludzkość ${ }^{8}$. Dla

du thème anthropologique de la jeune tradition Romaine dans l'oeuvre d'Irenée de Lyon, II, Strasbourg 1972, 521.

${ }^{3}$ Por. F.R. Tennant, The Sources of the The Fall and Original Sin, New York 1968, 288.

${ }^{4}$ Por. J. Vives, Pecado original y progreso evolutivo del hombre en Ireneo, EE 43 (1968) 564565 , nota 6.

${ }^{5}$ Por. Y. de Andia, Incorruptibilité et divinisation de l'homme selon Irénée de Lyon, Paris 1986, 118.

${ }^{6}$ Irenaeus, Demonstratio apostolicae praedicationis 33, ed. A. Rousseau, SCh 406, Paris 1995 , 128-130, tłum. W. Myszor: Ireneusz z Lyonu, Wykład nauki apostolskiej, ŹMT 7, 51-52.

${ }^{7}$ Por. Lassiat, Pour une théologie de l'homme, II, s. 511.

${ }^{8}$ Por. T. Dekert, Teoria rekapitulacji Ireneusza z Lyonu $w$ świetle starożytnych koncepcji na temat Adama, Kraków 2007, 38-39. 
opisania tej rzeczywistości Ireneusz używa niezwykle sugestywnego porównania stworzenia Adama z uzdrowieniem niewidomego dokonanym przez Jezusa. Celem tego wywodu jest ukazanie, że ten sam Bóg, który stworzył świat na początku, teraz dokonuje jego odkupienia, ale przy okazji dowiadujemy się, że Ireneusz widział w Adamie całą ludzkość, czyli zagubioną owcę, którą odnajduje Chrystus:

„Gdy uczniowie Go pytali, dlaczego człowiek ten był ślepy od urodzenia, czy to była wina jego, czy jego rodziców, odpowiedział: «Nie zgrzeszył ani on, ani jego rodzice, lecz aby objawiły się w nim dzieła Boże» (J 9, 3). A dzieła Boże to stworzenie człowieka. Tak bowiem tego dokonał, jak to opisuje Pismo: «I wziął Bóg błoto z ziemi i stworzył człowieka» (Rdz 2, 7). Dlatego i Pan splunął na ziemię i uczynił błoto, i nałożył je na oczy (J 9, 6), ukazując, w jaki sposób powstało dawne stworzenie (antiquam plasmationem) i tym, którzy mogli zrozumieć, objawił rękę Boga, którą człowiek został stworzony $\mathrm{z}$ błota. To, co Słowo-twórca pominęło w łonie matki, jawnie dopełniło, aby objawiły się w nim dzieła Boże i byśmy nie szukali innej ręki, która stworzyła człowieka ani innego Ojca, wiedząc, że ręka Boga, która stworzyła nas na początku i stwarza w łonie matki, ta sama ręka w ostatnich czasach wyszukała nas zagubionych, odzyskała i wzięła na ramiona zagubioną owcę (Łk 15, 4-6), i z radością przywróciła ją do stada życia"9.

Ireneusz kładzie wielki nacisk na fakt, że Chrystus we Wcieleniu musiał zrekapitulować tego samego człowieka, który był stworzony na początku, bo według niego Adam realnie zawiera w sobie wszystkich ludzi, wszystkie ludzkie pokolenia. Jeśli w Adamie są wszyscy ludzie, to wystarcza, aby Syn Boży odkupił Adama, by przez to zbawić całą ludzkość.

„Dlatego i Pan wyznaje, że będąc synem człowieczym, w sobie samym zrekapitulował owego pierwszego człowieka, z którego powstało ukształtowanie (plasmatio) narodzone z kobiety, aby jak przez pokonanego człowieka rodzaj nasz zszedł ku śmierci, tak abyśmy przez człowieka zwycięzcę na powrót powstali do życia i jak przez człowieka śmierć odniosła zwycięstwo nad nami, tak byśmy ją na nowo zwyciężyli dzięki człowiekowi”"

Patrząc z tej perspektywy Ireneusz przyznaje, że wszyscy mają udział w Odkupieniu tak samo jak mieli udział w grzechu Adama, bo wszyscy „W jakiś sposób” byliśmy w Adamie. W jaki sposób? Zdaje się, że chodzi tu o realną jedność ludzkiej natury, czyli ludzkości. Ireneusz nie przypadkiem używa formuły „, Adamie"11. Wyraża za jej pośrednictwem przekonanie, że Adam w jakiś sposób jest całą ludzkością. A zatem grzech Adama sam w sobie oraz związana z nim utrata szczęścia (zbawienia) musiały objąć

\footnotetext{
${ }^{9}$ Irenaeus, Adversus haereses V 15, 2, SCh 153, 204-206, thum. własne.

${ }^{10}$ Tamże V 21, 1, SCh 153, 260-264, tłum. własne.

${ }^{11}$ Por. tamże V 16, 3, SCh 153, 220.
} 
całą ludzkość. Osobisty grzech Adama stał się więc grzechem całej ludzkiej „natury”"

2. Metody z Olimpu i Grzegorz z Nyssy. Ireneusz miał kolosalny wpływ na rozwój teologii na Wschodzie dzięki temu, że pisał po grecku, i na Zachodzie, ponieważ przez długi czas był biskupem Lyonu. Wielu bardziej uzdolnionych Ojców przejęło i rozwinęło jego myśl, wielu mniej zdolnych przejęło wyrażenia, nie zastanawiając się nad ich głębią. Przekonanie Ireneusza o jedności ludzkiej natury w Adamie rozwinęli i pogłębili w największej mierze Metody z Olimpu i Grzegorz z Nyssy.

Metody z Olimpu mówi wprost:

„W Adamie przekroczyliśmy Twoje przykazanie”'13.

Niewielu jest na świecie badaczy zajmujących się nauką Metodego z Olimpu, ale nawet wśród tych kilku zdania są podzielone. Katharina Bracht uważa, że Metody widzi w pierwszych ludziach uosobienie gatunku i nie zakłada żadnej duchowej jedności Adama z innymi ludźmi, lecz Adam stanowi jedynie przykład losu wszystkich ludzi ${ }^{14}$. A jednak - jak mi się wydaje - Metody wyraźnie twierdzi, iż dzięki realnej jedności ludzkości rzeczywiście byliśmy w raju i braliśmy udział w pierwszym grzechu. Ponadto uznaje swoją osobistą odpowiedzialność za grzech Adama ${ }^{15}$, a przecież nie czułby się winny za przykład, jaki ktoś mu dał. Za Ireneuszem powtarza, że „w Adamie” cały rodzaj ludzki usłyszał przykazanie Boga i jednocześnie z Adamem przekroczył ów nakaz. Jak to określił Theodorus Badurina, razem z nim okazaliśmy się krnąbrni jakbyśmy byli jedną osobą ${ }^{16}$.

Podstawą przekonania Metodego o naszym udziale w grzechu Adama jest, tak samo jak u Ireneusza, analogia do jedności wszystkich w Chrystusie. Adam także dla Metodego oznacza zarówno człowieka w ogóle, jak i konkret-

${ }^{12}$ Por. L. Scheffczyk, Urstand, Fall und Erbsünde: von der Schrift bis Augustinus, Freiburg 1981, 63.

${ }^{13}$ Methodius, De resurrectione III 23, 3, ed. G. Bonwetsch, GCS 27, Leipzig 1917, 281, thum. własne.

${ }^{14}$ Por. K. Bracht, Vollkommenheit und Vollendung: Zur Anthropologie des Methodius von Olympus, Tübingen 1999, 102n.

${ }^{15}$ Methodius, De resurrectione II 2, 1, GCS 27, 191, tłum. własne: „Po nadaniu przykazania diabeł miał sposobność wzbudzić we mnie namiętność poprzez przykazanie, bo pobudzał mnie i nakłaniał nieustannie do pożądania tego, co zabronione”. Por. tamże II 2, 4, GCS 27, 191n, tłum. własne: „Zachęta Boga i nakaz dane mi dla życia i nieśmiertelności, abym im posłuszny i żyjąc zgodnie z nimi miał radość oraz życie na wieki szczęśliwe, nieustannie kwitnące i prowadzące do nieśmiertelności, okazały się dla mnie zbuntowanego śmiercią i przekleństwem, skoro diabeł, którego Apostoł teraz nazywa grzechem, bo jest sprawcą i wynalazcą grzechu, widząc okazję w przykazaniu nakłonił mnie do nieposłuszeństwa, a zwiedzionego zabił, czyniąc mnie odpowiedzialnym za nie: «W dniu, w którym zjecie z niego, umrzecie» (Rdz 2, 17)".

${ }^{16}$ Por. T. Badurina, Doctrina S. Methodii de Olympio de peccato originali et de eius effectibus, Romae 1942, 58n. 
ną pierwszą osobę. Podobnie do Ireneusza, Metody kładzie wielki nacisk na fakt, że Chrystus wcielając się, przyjął dokładnie tę samą substancję, z której został stworzony Adam. Idzie nawet dalej niż Ireneusz, twierdząc, że Chrystus przyodział się w Adama:

„Słowo podniosło człowieka, aby po pokonaniu węża unieważnić wyrok potępienia wydany na skutek upadku. Wypadało bowiem, żeby zły duch został pokonany nie przez kogo innego, lecz przez tego właśnie, kogo oszukał, i chełpił się, że nad nim zapanował. Nie można byłoby inaczej rozbić grzechu i usunąć potępienia, gdyby ten sam człowiek, któremu powiedziano: «Z ziemi powstałeś i do ziemi powrócisz», nie wznowił walki i nie unieważnił wyroku, z jego powodu wydanego na wszystkich; chodzi o to, aby jak dawniej w Adamie wszyscy umarli, tak teraz wszyscy zostali ożywieni w Chrystusie, który w Adama się przyodział"17.

Jak wyjaśnia Lloyd George Patterson, trudne stwierdzenie, że Chrystus stał się tym samym co Adam, nie oznacza, że Adam był pierwszym wcieleniem Słowa, lecz odzwierciedla założenie Metodego oparte o naukę Ireneusza, że Słowo jest w relacji do ciała Adama i że Wcielenie oznacza przyjęcie przez Słowo naszej obecnej ludzkiej natury ${ }^{18}$. Z tej perspektywy można rozumieć Adama jako antycypację wcielenia Chrystusa. Zdaje się zatem, że przyodzianie się Syna Bożego w Adama jest nieco zmienioną wersją Ireneuszowej typologii Adam-Chrystus.

Podobny realizm znajdziemy u Grzegorza z Nyssy. Mówiąc o pierwszym grzechu Grzegorz używa porównania upadku ludzkiej natury do zabłąkania się owcy, o której wspominał Jezus w przypowieści Łk 15, 1-7. Porównanie to bardzo sugestywnie ukazuje jedność ludzkiej natury, która jest tak realna, że aż można mówić o ludzkiej naturze jako o jednym organizmie:

„Sprawca naszego zbawienia szuka zagubionej owcy. To my, ludzie, jesteśmy ową zagubioną owcą, odciągniętą przez grzech od stada stu rozumnych owiec"19.

W tekstach, w których porównuje ludzką naturę do zagubionej owcy ${ }^{20}$, Grzegorz nie przywołuje nigdzie Adama, a mówi wyłącznie o grzechu czło-

${ }^{17}$ Methodius, Convivium decem virginum III 6, PG 18, 68, thum. S. Kalinkowski: Metody z Olimpu, Uczta, w: Pierwsze pisma greckie o dziewictwie, opr. J. Naumowicz, ŹM 16, Kraków Tyniec 1997, 153.

${ }^{18}$ Por. L.G. Patterson, Methodius of Olympus. Divine Sovereignty, Human Freedom and Life in Christ, Washington 1997, 133.

${ }^{19}$ Gregorius Nyssenus, Antirrheticus adversus Apollinarem, ed. F. Müller, GNO 3/1, Leiden 1958, 152, tłum. własne.

${ }^{20}$ Por. Gregorius Nyssenus, Contra Eunomium III 2, 49, ed. W. Jaeger, GNO 2, Leiden $1960^{2}$, 68; III 10, 12, GNO 2, 293-294; tenże, In canticum canticorum hom. 12, ed. H. Langerbeck, GNO 6, Leiden 1960, 364; tenże, In inscriptiones psalmorum hom. 2, ed. J. Mc Donough - P. Alexander, GNO 5, Leiden 1962, 86; tenże, In Ecclesiasten hom. 2, GNO 5, 305. 
wieka. Stało się to podstawą do zarzutu, że Grzegorz w ogóle nie odwołuje się do grzechu Adama, a mówi ogólnie o grzechu człowieka, rozumianym jako suma grzechów wszystkich ludzi ${ }^{21}$. Nie jest to jednak prawda. W co najmniej jednym miejscu Grzegorz mówi o zabłąkaniu owcy - ludzkiej natury z wyraźnym odwołaniem do Adama:

„Chociaż pierwszy człowiek przeżył po nieposłuszeństwie jeszcze wiele setek lat, jednak Bóg nie skłamał mówiąc: «W dniu w którym skosztujecie [owocu] umrzecie». Z powodu oddzielenia od prawdziwego życia tego samego dnia zapadł na niego wyrok śmierci, a później, po latach, doścignęła Adama śmierć cielesna. Ten, który po to przyszedł, by ożywić i ocalić to, co zginęło, co w przypowieści pasterz nazywa owcą, znajduje to, co zginęło i, zmieszawszy z Bóstwem i duszę, i ciało, bierze na swoje ramiona całą owcę, nie tylko jej skórę, aby uczynić człowieka Bożego zdrowym"²2.

Zdaje się zatem, że momentem upadku ludzkiej natury, który Grzegorz nazywa odłączeniem się owcy od stada stworzeń rozumnych jest historyczny grzech pierwszego człowieka - Adama. Wielokrotnie Grzegorz mówi, że zostaliśmy wygnani z raju razem z Adamem ${ }^{23}$. Można by uznać, że Grzegorz ma tu na myśli tylko nasz udział w skutkach grzechu, a nie w samym upadku Adama. A jednak nie. Mówi bowiem:

„My ludzie, wszyscy bez wyjątku, jak gdyby w nas żył Adam, musimy patrzeć na ubrania ze skór i liści cielesnego życia, które sprawiliśmy sobie po utracie wiecznej i wspaniałej szaty, przyoblekając się w miejsce szaty Bożej w hulanki, próżną sławę i przemijające uciechy cielesne"24.

Chyba po raz pierwszy widzimy tu tak wyraźnie właściwy dla Ojców greckich sposób rozumienia grzechu pierworodnego. Jak słusznie zauważa Stanislas Lyonnet, między alternatywą, polegającą na dopatrywaniu się źródła zła w osobistych grzechach każdego, a uznaniem grzechu dziedziczonego od Adama istnieje jeszcze trzecia możliwość. Ojcowie greccy mówią bowiem o naśladowaniu przestępstwa Adama, ale nie w sposób, w jaki naśladowanie rozumiał Pelagiusz. Nie jest to naśladowanie podobne do naśladowania modelu przez artystę, ale raczej podobne do instynktownego naśladowania rodzi-

${ }^{21}$ Por. J. Vives, El pecado original en San Gregorio de Nisa, w: Pecado original, XXIX Semana Española de Teología, Madrid 1970, 176.

${ }^{22}$ Gregorius Nyssenus, Refutatio confessionis Eunomii 175, ed. W. Jaeger, GNO 2, 385-386, thum. własne.

${ }^{23}$ Por. tenże, De viriginitate 12, ed. J.P. Cavarnos, GNO 8/1, Leiden 1963, 302; tenże, Adversus eos, qui baptismum differunt, PG 46, 417; tenże, De oratione dominica V, ed. J.F. Callahan, GNO 7/2, Leiden 1992, 66; tenże, De oratione dominica 1, GNO 7/2, 211n; tenże, De opificio hominis 17, PG 44, 188.

${ }^{24}$ Tenże, De oratione dominica V, GNO 7/2, 65, tłum. W. Kania: Grzegorz z Nyssy, Pięć homilii o modlitwie Pańskiej, w: Modlitwa Pańska. Komentarze greckich Ojców Kościoła IV-V w., red. K. Bielawski, Kraków 1995, 74. 
ców przez dziecko. Całkowicie wolne akty, za które jesteśmy w pełni odpowiedzialni, są jednocześnie konsekwencjami choroby grzechu, z którą natura zetknęła się w wyniku nieposłuszeństwa Adama ${ }^{25}$. Dopiero w tej perspektywie można pojąć, jak Grzegorz, mówiąc o grzechu, jaki dokonał się w raju, mógł nie robić żadnej różnicy między Adamem i jego potomstwem. Julius Gross zwraca uwagę, że jest to zrozumiałe, jeśli weźmie się pod uwagę jego realizm gatunkowy: skutki grzechu dotykają całej ludzkiej natury, a zatem i wszystkich jednostek, dla których jest ona wspólna. Sam Grzegorz mówi wprost o tym, że ludzka natura jako jedność popełniła pierwszy grzech:

„Po tym, jak ludzka natura popadła w grzech, Bóg w naszym upadku nie porzucił nas bez pomocy, lecz przy każdym człowieku postawił anioła, który ma niecielesną naturę, aby nam pomagał w życiu"26.

Grzech pierworodny - według Grzegorza - jest zatem, jak wyjaśnia José Vives, grzechem natury w tym sensie, że udziela się lub przekazuje wszystkim członkom natury przez samo uczestnictwo $\mathrm{w}$ naturze ${ }^{27}$.

3. Inni Ojcowie greccy. Nie znajdziemy u pozostałych Ojców przed Augustynem tak spójnej koncepcji udziału ludzkości w grzechu Adama, opartej na przekonaniu o realnej jedności ludzkiej natury, jaką widzieliśmy u Ireneusza, Metodego z Olimpu i Grzegorza z Nyssy. Nie znaczy to, że żaden inny Ojciec nie wierzył w solidarność ludzi z Adamem. Orygenes wśród licznych swoich hipotez podaje i takie, w których mówiąc o pierwszym człowieku, czy też o pierwszym upadku, zakłada, że Adam symbolizuje lub reprezentuje całą ludzkość ${ }^{28}$. Najwyraźniej przedstawia tę ideę w Contra Celsum. Odwołuje się do znaczenia imienia Adam, które oznacza „człowiek” i na tej podstawie widzi w Adamie uosobienie całego rodzaju ludzkiego.

„Skoro zaś Celsus powiada, że opowiadanie Mojżesza bezbożnie przedstawia Boga od początku jako tak słabego, że nie mógł zmusić do posłuszeństwa jednego człowieka, którego sam stworzył, odpowiemy, że mówi podobnie jak ktoś, kto by ganił Boga za to, że istnieje zło, od którego Bóg nie mógł ocalić nawet jednego człowieka, tak że nie ma istoty ludzkiej nie splamionej grzechem. Jak bowiem ci, którym zależy na obronie Opatrzności, bronią jej za pomocą wielu poważnych argumentów, tak samo o Adamie i jego grzechu będą rozprawiać ci, którzy wiedzą, że «Adam» w języku hebrajskim oznacza człowieka i że to, co Mojżesz mówi o Adamie, odnosi się do natury ludzkiej. Albowiem, jak powiada Pismo, «w Adamie wszyscy umierają» (1Kor 15, 22)

${ }^{25}$ Por. S. Lyonnet, Le péché originel et l'exégèse de Rom. 5, 12-14, RSR 44 (1956) 70.

${ }^{26}$ Gregorius Nyssenus, De vita Moysis II 45, ed. J. Daniélou, SCh 1bis, Paris 1987, 130-132; thum. S. Kalinkowski: Grzegorz z Nyssy, Życie Mojżesza, ŹMT 50, Kraków 2009, 49.

${ }^{27}$ Por. J. Vives, El pecado original en San Gregorio de Nisa, EE 45 (1970) 189.

${ }^{28}$ Por. Origenes, Commentarius in Joannem XIII 37, 239-241, ed. C. Blanc, SCh 222, Paris 1975, 158-160; tenże, In Leviticum hom. 6, 2, ed. M. Borret, SCh 286, Paris1981, 276-278. 
i zostali potępieni za «przestępstwo podobne do przestępstwa Adama» (Rz 5, 14). Tak więc Pismo Święte mówi nie o jednym człowieku, lecz o całym rodzaju ludzkim; z dalszego ciągu słów odnoszących się jak gdyby do jednego człowieka można przecież wywnioskować, że przekleństwo Adama jest wspólne wszystkim ludziom, podobnie jak przekleństwo kobiety odnosi się do wszystkich kobiet. Również opowiadanie o tym, że mężczyzna i kobieta zostali wypędzeni z raju odziani w szaty ze skórek $(\operatorname{Rdz} 3,21)$, które Bóg dał grzesznikom z powodu ludzkiego przestępstwa, zawiera tajemnicę wspanialszą niż mit Platona o duszy, która straciwszy skrzydła spada, «aż coś stałego napotka, uchwyci i zamieszka tam» ${ }^{29 " 30}$.

Na podstawie etymologii Adam = człowiek Orygenes odnosi to, co Pismo mówi o naszym prarodzicu, do całego rodzaju ludzkiego. Adam symbolizuje i reprezentuje całą ludzkość. Manlio Simonetti zwraca jednak uwagę, że Orygenes nie wyjaśnia, w jaki sposób się to dzieje, czy dlatego że wszyscy pochodzą od Adama, czy z innego powodu ${ }^{31}$. Istnieje także grupa tekstów, w których Orygenes nie traktuje Adama jako typ czy symbol ludzkości, ale mówi o jedności o wiele głębszej. Najbardziej wyraźną wypowiedzią Orygenesa na ten temat jest fragment z Komentarza do Listu św. Pawła do Rzymian, w którym twierdzi, że wszyscy ludzie byli w lędźwiach Adama.

„Wszyscy ludzie, którzy rodzą się na tym świecie i którzy się urodzili, byli w lędźwiach Adama, kiedy ten jeszcze przebywał w raju i wszyscy ludzie wraz z nim albo w nim (cum ipso vel in ipso) zostali wypędzeni z raju, kiedy on został wygnany; i logicznie - śmierć, która spadła na niego na skutek przestępstwa, przez niego przeszła na tych, którzy byli w jego lędźwiach" 32 .

Jedność, którą tworzyliśmy w Adamie, była zapowiedzią naszej jedności w Chrystusie. Więcej nawet, już jedność w Adamie była możliwa tylko dzięki Chrystusowi:

„Skoro Chrystus jest kamieniem węgielnym, to do całości, na którą składają się wszystkie istoty zbawione należy odnieść stwierdzenie, iż jednorodzony Chrystus jest wszystkim we wszystkich: początkiem jest w człowieku, którego przybrał, końcem zaś w ostatnim ze świętych. Znajduje się też w istotach pośrednich. Albo inaczej: początkiem był w Adamie, a końcem podczas swego pobytu na ziemi, zgodnie ze zdaniem: «Ostatni Adam był duchem oży-

${ }^{29}$ Plato, Phaedrus 25, 246b-c.

${ }^{30}$ Origenes, Contra Celsum 4, 40, ed. M. Borret, SCh 136, Paris 1968, 288-290, thum. S. Kalinkowski: Orygenes, Przeciw Celsusowi, Warszawa 1986, 210-211.

${ }^{31}$ Por. M. Simonetti, Alcune osservazioni sull'interpretazione origeniana di Genesi 2, 7 e 3, 21, „Aevum” 36 (1962) 374.

${ }^{32}$ Origenes, Commentarii in Epistulam ad Romanos 5, 12, ed. C.P. Hammond Bammel - M. Fédou - L. Brésard, SCh 539, Paris 2010, 364-366, tłum. S. Kalinkowski: Orygenes, Komentarz do Listu św. Pawła do Rzymian, PSP 57/1, Warszawa 1994, 251. 
wiającym» (1Kor 15,45$)$. Określenie to zgadza się z definicją «pierwszego i ostatniego»>"33.

W cytowanym fragmencie Orygenes wraca do charakterystycznej dla Ireneusza typologii Adam - Chrystus, chociaż nie uznaje jego idei realnej jedności ludzkiej natury, a poprzestaje na przyznaniu jej jedności opartej na mistycznej solidarności wszystkich z Chrystusem. Nie wolno, oczywiście, zapominać o wielkim nacisku, jaki Orygenes kładł na znaczenie ludzkiej wolnej woli. To właśnie przekonanie doprowadziło go aż do koncepcji upadku umysłów w preegzystencji ${ }^{34}$. Rzecz jasna, nie da się pogodzić koncepcji jedności ludzkości z ideą upadku w preegzystencji, trzeba je traktować jako dwie odrębne hipotezy. Kluczowe mimo to wydaje mi się przekonanie Orygenesa, że wszyscy ludzie są grzeszni, wszyscy potrzebują chrztu i odkupienia Chrystusa. W jaki sposób doszło do tego skażenia grzechem - czy ludzkość stanowi jedność, czy każdy sam popełnia grzech - pozostaje dla niego kwestią otwartą. Orygenes stwierdza także z całą pewnością, że człowiek został od początku obdarzony wolną wolą i nawet po grzechu wolną wolę zachował. Te dwa fakty - wolna wola i powszechność grzechu - są dla niego niepodważalne i dlatego skupia się na ukazaniu ich współistnienia. Ich wyjaśnienie wydaje się dla niego kwestią drugorzędną.

Kilka wzmianek, które można interpretować jako świadectwo przekonania o jedności ludzkości w Adamie, znajdujemy także u Dydyma Ślepego. Nigdzie nie mówi on wprost o solidarności z Adamem, ale kilkakrotnie nazywa występek Adama «naszym nieposłuszeństwem». Najczęściej cytowany przez badaczy tekst pochodzi z De Trinitate i brzmi następująco:

„«Z Jego pełni my wszyscy otrzymaliśmy łaskę za łaskę» $(\mathrm{J} 1,16)$. To znaczy odrodzenie za łaskę, którą odrzuciliśmy, gdy przekroczyliśmy pierwsze Boże przykazanie dotyczące jednego drzewa"35.

Dydym łączy ze sobą wyrażenia ,nasz brud” i ,dawny grzech” jako określenia tej samej rzeczywistości:

„Pan został ochrzczony z powodu planu względem węża, którego zawierały wody Jordanu, w paszczy, jak zagadkowo mówi Hiob, aby [go] zabić, aby zetrzeć nasz brud i wybaczyć dawny grzech"36.

${ }^{33}$ Tenże, Commentarius in Joannem I 31, 225, ed. C. Blanc, SCh 120bis, Paris 1996, 170, thum. S. Kalinkowski: Orygenes, Komentarz do Ewangelii wedtug św. Jana, ŹMT 27, Kraków 2003, 68.

${ }^{34}$ Por. tenże, De principiis I 5, 3, ed. H. Crouzel - M. Simonetti, SCh 252, Paris 1978, 178-182; I 8, 4, SCh 252, 228-232; II 8, 3-4, SCh 252, 342-348; III 5, 4, SCh 268, Paris 1980, 224-226.

${ }^{35}$ Didymus Caecus, De Trinitate 1, 27, PG 39, 401, tłum. własne. Podobnie w dalszym ciągu tego samego traktatu: „Wy którzy zostaliście włączeni w Chrystusa przez chrzest, - mówi Pismo - przyoblekliście Chrystusa; przyjmujemy także ów opisany [w Piśmie] obraz i podobieństwo do Boga, które otrzymaliśmy przez Boskie tchnienie i utraciliśmy przez grzech i z powrotem okazujemy się tacy, jacy powstaliśmy za naszego protoplasty - to właśnie oznacza obraz i podobieństwo" (tamże 2, 12, PG 39, 680, tłum. własne).

${ }^{36}$ Tamże 2, 12, PG 39, 684, tłum. własne. 
I jeszcze raz w De Trinitate mówi o Chrystusie, że przyszedł zniszczyć „nasze dawne nieposłuszeństwo" 37 , a dzięki poprzednim fragmentom możemy wnioskować, że owo „dawne nieposłuszeństwo” to grzech Adama. Dydym wiąże $\mathrm{w}$ jakiś sposób grzech Adama z obecną grzeszną kondycją całej ludzkości, choć poprzestaje na stwierdzeniu tego związku, nie podając żadnego jego wyjaśnienia. Mówi mianowicie:

„Wszyscy ludziesąpod grzechem, ponieważAdamokazałnieposłuszeństwo”38.

Leo Scheffczyk uważa, że Dydym przyznaje historyczną realność grzechowi w raju i łączy go z pochodzącą od Ireneusza tradycją mówiącą, że „my” zgrzeszyliśmy w Adamie ${ }^{39}$. Także J. Gross podkreśla, że jak wielu jego poprzedników Dydym utożsamia wszystkich ludzi z pierwszym rodzicem, który przekroczył Boże przykazanie. Dodaje, że teksty te sprawiają wrażenie, iż Dydym przyjął realizm Ireneusza, zgodnie z którym dusze wszystkich potomków Adama były jakoś zawarte $\mathrm{w}$ pierwszym rodzicu i w ten sposób miały udział w jego upadku. Bez wątpienia Dydym podkreśla swoim niezwykle realistycznym językiem solidarność, która łączy Adama z jego potomkami. Pozostaje pytanie, czy rozciąga tę solidarność na grzech. Z pewnością uczy, że grzech spowodował dla wszystkich dzieci Adama utratę pierwotnej łaski, która polegała na podobieństwie do Boga ${ }^{40}$.

Grzegorz z Nazjanzu tylko raz mówi wprost o naszym udziale czy uczestnictwie w Adamie i to w kontekście zbawienia w Chrystusie. Jest to fragment Mowy 33:

„Jedna jest wspólna ziemia, matka i grób: z niej powstaliśmy, do niej wrócimy, i nikt nie będzie miał więcej niż inni. Coś jednak cenniejszego mamy wspólnie, mianowicie Słowo [Boże], Prawo i proroków, Mękę Chrystusową: dzięki temu wszystkiemu doznaliśmy odrodzenia, wszyscy bez wyjątku, gdyż wszyscy mieliśmy udział w tym samym Adamie, wszyscy daliśmy oszukać się przez węża, wszyscy umarliśmy z powodu grzechu, wszyscy zostaliśmy zbawieni w niebiańskim Adamie, wszyscy poprzez drzewo hańby wróciliśmy do drzewa żywota, od którego kiedyś odpadliśmy"41.

Nie jest to jednak całość nauczania Grzegorza na temat solidarności ludzkości z Adamem. W jakiś sposób utożsamia wszystkich ludzi z Adamem, bo zdarza mu się mówić o wydarzeniach z raju jako dotyczących nas wszystkich ${ }^{42}$,

${ }^{37}$ Por. tamże 3, 12, PG 39, 860.

${ }^{38}$ Tenże, Fragmenta in Epistulam II ad Corinthios, PG 39, 1692, tłum. własne.

${ }^{39}$ Por. Scheffczyk, Urstand, Fall und Erbsünde, s. 130.

${ }^{40}$ Por. J. Gross, Geschichte des Erbsündendogmas. Ein Beitrag zur Geschichte des Problems vom Ursprung des Übels, I, München 1960, 135n.

${ }^{41}$ Gregorius Nazianzenus, Oratio 33, 9, PG 36, 225, thum. zbiorowe: Św. Grzegorz z Nazjanzu, Mowy wybrane, red. S. Kazikowski, Warszawa 1967, 388.

${ }^{42}$ Por. tamże 45, 8, PG 36, 633, Mowy wybrane, 534: „Biada mojej słabości; gdyż moją jest słabość pierwszego rodzica!”; 45, 12, PG 36, 637-640, Mowy wybrane, 536: „Oto więc, skoro po 
tak jak nas wszystkich dotyczy Odkupienie ${ }^{43}$. Grzegorz odnosi do wszystkich ludzi nie tylko skutki grzechu Adama, ale także same wydarzenia w raju, jakbyśmy realnie mieli w nich udział. Bardzo wyraźnie mówi o naszym udziale w upadku i wygnaniu z raju w Mowie 19:

„Oby przepadła nieprawość, i pierwsza jej podstawa, i zły duch, który nam śpiącym posiał kąkole, aby początkiem złego stało się zaniedbanie dobrego, tak jak początkiem ciemności jest ustąpienie światła. To sprawiło drzewo i gorzkie skosztowanie owocu, i zawistny wąż, i nieposłuszeństwo, za które trzeba prowadzić życie w pocie czoła. W wyniku tego jestem nagi, okryty hańbą, poznałem nagość, przyoblekłem skórzaną szatę, wypędzony z raju, odwróciłem się ku ziemi, z której byłem wzięty, mając taki tylko pożytek z doznanej przyjemności, że znam swoje nieszczęścia. Za małą rozkosz zostałem skazany na nie kończący się smutek i na wojnę z tym, który na moją zgubę okazał mi przyjaźń i zwiódł mnie dając skosztować owocu. To jest moja nagroda za grzech, dlatego w trudzie urodziłem się, i żyję, i umieram"”4

Jak pisze Jan Maria Szymusiak, Grzegorz przyjmuje pewną wspólną odpowiedzialność, wprawdzie całkiem mistyczną, ale rzeczywistą. Nasz udział w grzechu Adama jest analogiczny do naszego udziału w dziele Chrystusa, czyli bardzo realny, a Chrystus zawiera w sobie całą ludzkość zbawioną, tak jak Adam zawiera w sobie wszystkie pokolenia grzeszników ${ }^{45}$. L. Scheffczyk twierdzi nawet, że powyższe wypowiedzi często sprawiają wrażenie, że Grzegorz mówi o formalnym udziale ludzkości w grzechu Adama ${ }^{46}$. Rzeczywiście Grzegorz wyjątkowo mocno podkreśla jedność i solidarność ludzkości z Adamem. Nie wyjaśnia jednak nigdzie, w jaki sposób ta jedność została zbudowana i gdzie ma swoją podstawę. Tam, gdzie Orygenes czy Grzegorz z Nyssy silą się na wyjaśnienia, Grzegorz pozostaje jedynie przy stwierdzeniu ciężaru pierworodnego upadku ${ }^{47}$.

4. Ojcowie lacińscy. Do tej pory cytowałam wypowiedzi Ojców greckich, nie znaczy to jednak, że idea solidarności ludzkości z Adamem była obca Ojcom łacińskim. Co prawda, nie znajdziemy u żadnego z nich dopracowanej koncepcji jedności wszystkich z pierwszym rodzicem, jednak ich stwierdzenia są ważne i znaczące. Już u Tertuliana znajdziemy kilka fragmentów, których

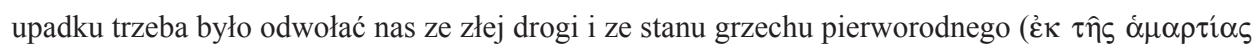

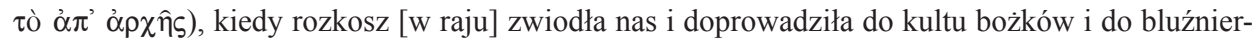
czego składania krwawych ofiar, skoro trzeba było nas przywrócić do pierwotnego stanu [łaski], sądzę, że zbawienia musiało dokonać miłosierdzie Boga, Ojca naszego, który nie chciał stracić tak wielkiego dzieła swej ręki, jakim był człowiek".

${ }^{43}$ Por. tamże 38, 4, PG 36, 316, Mowy wybrane, 417: „Jeśli skosztowanie owocu nas potępiło, to o ileż więcej męka Chrystusa nas usprawiedliwiła".

${ }^{44}$ Tamże 19, 14, PG 35, 1060, Mowy wybrane, $215 \mathrm{n}$.

${ }^{45}$ Por. J.M. Szymusiak, Grzegorz Teolog, Poznań 1965, 192.

${ }^{46}$ Por. Scheffczyk, Urstand, Fall und Erbsünde, s. 139.

${ }^{47}$ Por. J.M. Szymusiak, Grégoire de Nazianze et la péché, StPatr 9 (1966) 299. 
pominąć nie sposób i które można interpretować jako stwierdzenia udziału wszystkich ludzi w przestępstwie Adama. Zazwyczaj jako najważniejszy tekst cytuje się De anima 40:

„Każda dusza dopóty uważa się [za będącą] w Adamie, dopóki nie mogłaby być uznana [za będącą] w Chrystusie (omnis anima eo usque in Adam censetur, donec in Christo recenseatur); tak długo [pozostaje] nieczysta, jak długo nie mogłaby być uznana, jest grzesznicą, ponieważ jest nieczysta, a hańbi ją wspólnota z ciałem"48.

L. Scheffczyk powołując się na ten fragment uznaje, że Tertulian widzi przynależność każdego człowieka do Adama i na tym bazuje swoje rozumienie jedności Chrystusa z ludzkościąa ${ }^{49}$. Rzeczywiście, jeśli uwzględnimy całość jego nauczania, a przede wszystkim przekonanie o fizycznej jedności całej ludzkiej natury ${ }^{50}$, możemy tak ten fragment rozumieć. Tertulian uznaje bowiem, że wszyscy ludzie - zarówno pod względem ciała, jak i duszy - fizycznie pochodzą od Adama ${ }^{51}$. To pochodzenie jest „w jakiś sposób” źródłem naszego uczestnictwa w Adamie, w jego winie i karze za tę winę, co Tertulian stwierdza bardzo wyraźnie:

„Jak nosiliśmy obraz ziemskiego człowieka, nośmy obraz niebiańskiego.

Nosiliśmy obraz ziemskiego człowieka przez wspólnotę wykroczenia, przez udział w śmierci, przez wygnanie z raju"s2.

Nie znajdziemy jednak u Tertuliana żadnej próby szczegółowego wyjaśnienia, na jakiej zasadzie zostaliśmy włączeni w tę wspólnotę przewinienia, śmierci i wygnania $z$ raju.

Następne znaczące wypowiedzi znajdziemy dopiero u piszącego w wieku IV tajemniczego autora zwanego Ambrozjastrem. Znany jest on przede wszystkim z ukucia stwierdzenia, że ludzie zgrzeszyli w Adamie jakby w masie. Przyjrzyjmy się samemu tekstowi:

„«W którym - to jest w Adamie - wszyscy zgrzeszyli» (Rz 5, 12). Powiedział «w którym», mimo że mówił o kobiecie, ponieważ nie odniósł się do postaci, ale do rodzaju (genus). Jest więc jasne, że wszyscy ludzie zgrzeszyli w Adamie jakby w masie (quasi in massa). Ponieważ bowiem on sam był zepsuty przez grzech, wszyscy ci, których zrodził, narodzili się pod grzechem. Dlatego więc od niego wszyscy jesteśmy grzesznikami, ponieważ wszyscy od niego pochodzimy"s3.

${ }^{48}$ Tertullianus, De anima 40, PL 2, 719, thum. własne.

${ }^{49}$ Por. Scheffczyk, Urstand, Fall und Erbsünde, s. 95.

${ }^{50}$ Por. Tertullianus, De anima 27, PL 2, 696.

${ }^{51}$ Por. tamże 19, PL 2, 681n.

${ }^{52}$ Tenże, De resurrectione carnis 49, PL 2, 866, thum. własne.

${ }^{53}$ Ambrosiaster, Commentarii in Epistolam ad Romanos 5, 12, PL 17, 92, thum. J. Sulowski: Ambrozjaster, Komentarz do listu św. Pawła do Rzymian, ŹMT 19, Kraków 2000, 79-80. 
Uczeni interpretują ten tekst Ambrozjastra, przypisując mu przekonanie o solidarności czy wręcz jedności całej ludzkości z Adamem. Trzeba jednak pamiętać, że w sposób typowy dla Ojców greckich Ambrozjaster łączy przekonanie o jedności wszystkich z Adamem z twierdzeniem, że własne występki każdego są prawdziwym źródłem grzechu.

„Być zaprzedanym grzechowi, znaczy pochodzić od Adama, który pierwszy zgrzeszył i być siedliskiem grzechu na skutek własnego występku. Jak mówi prorok Izajasz: «za wasze winy zostaliście sprzedani» (Iz 50, 1). Adam bowiem pierwszy zaprzedał się i przez to całe jego potomstwo jest siedliskiem grzechu" ${ }^{\prime 4}$.

Realne uczestnictwo w grzechu Adama ma swoje źródło w naszym pochodzeniu od Adama. Nie chodzi jednak o dziedziczenie grzechu. W Adamie zgrzeszyliśmy wszyscy na mocy naszego uczestnictwa w „rodzaju” ludzkim. Wszyscy jesteśmy Adamem, ponieważ Adam jest „rodzajem” (genus), w którym uczestniczą wszyscy ludzie ${ }^{55}$. Należałoby więc powiedzieć, że grzech Adama to grzech „rodzaju” ludzkiego ${ }^{56}$. Ambrozjaster uważa bowiem cała ludzkość za jedną substancję ${ }^{57}$. Posuwa się nawet do stwierdzenia, że jeden człowiek jest obrazem jednego Boga ${ }^{58}$. Uznanie, że tylko pierwszy człowiek był obrazem Boga, a jego potomkowie już nie, byłoby absurdalne. Ambrozjaster nie waha się nawet powiedzieć, że Ewa także jest Adamem - w tym właśnie sensie, że Adam oznacza cały rodzaj ludzki ${ }^{59}$. Trzeba więc uznać, że Ambrozjaster widzi w pierwszym człowieku cały rodzaj ludzki, stworzony jako pewna jedność. Na tej podstawie Juan Bautista Valero precyzuje, że mówiąc o zgrzeszeniu wszystkich w Adamie Ambrozjaster ma na myśli grzech rodzajowy, który stanowi zaczątek czy też korzeń grzechów osobistych ${ }^{60}$.

Podobne przekonanie o jedności ludzkości w Adamie znajdziemy też u Ambrożego. Nie zadał on sobie jednak trudu, by wyjaśnić źródło naszej solidarności z Adamem. Dzięki podejściu praktycznemu i duszpasterskiemu skupiał się bowiem nie na ontologii, ale na problemach antropologicznych. Pytanie o początki zła i powszechność grzechu doprowadziło go do uznania solidarności wszystkich ludzi z Adamem:

„Bez wątpienia wszyscy zgrzeszyliśmy w pierwszym człowieku, a przez dziedzictwo natury zostało przeniesione z jednego na wszystkich dziedzictwo winy. Przeciwko komu zgrzeszyłem, przeciwko Ojcu czy Synowi?

${ }^{54}$ Tamże 7, 14, PL 17, 111-112, tłum. własne.

${ }^{55}$ Por. tamże 7, 25C, PL 17, 116, thum własne: „Przeciwnik pokonany mocą Chrystusa nie śmiał bronić człowiekowi, zjednoczonemu z Adamem poprzez ród (genere), by został przywrócony do pierwotnego stanu i by cały stał się nieśmiertelny".

${ }^{56}$ Por. J.B. Valero, Pecar en Adán según Ambrosiaster, EE 65 (1990) 152.

${ }^{57}$ Por. Ambrosiaster, Commentarii in Epistolam ad Romanos 11, 16, PL 17, 151.

${ }^{58}$ Por. tenże, Commentarii in Epistolam I ad Corinthios 11, 7, PL 17, 240.

${ }^{59}$ Por. tenże, Commentarii in Epistolam ad Romanos 5, 12, PL 17, 92.

${ }^{60}$ Por. Valero, Pecar en Adán según Ambrosiaster, s. 153. 
Oczywiście przeciwko Temu, który mi zaufał, zgrzeszyłem, sprzeniewierzając się. Nakazano człowiekowi, by kosztował wszystkiego, co było w raju, lecz by nie dotykał drzewa poznania dobra i zła. Adam więc jest w każdym $\mathrm{z}$ nas. W nim bowiem zawiniła cała ludzka natura (conditio humana), ponieważ przez jednego grzech przeszedł na wszystkich" ${ }^{\prime 1}$.

Na pewno Ambroży silniej niż Ambrozjaster podkreśla solidarność dzieci Adama z grzeszącym prarodzicem ${ }^{62}$. Podobnie jak Ireneusz uznaje więc solidarność całego rodzaju ludzkiego w Adamie ${ }^{63}$. Ambroży mówi bowiem o solidarności nie tylko w karze, ale i w winie:

„Upadłem w Adamie, $\mathrm{z}$ raju zostałem wygnany w Adamie, umarłem w Adamie" ${ }^{\circ 4}$.

W innym jeszcze miejscu Ambroży mówi o grzechu Adama, by zaraz utożsamić go z ,naszym” upadkiem:

„Jerycho bowiem jest figurą tego świata, do którego $\mathrm{z}$ raju, to jest $\mathrm{z}$ owej niebiańskiej Jerozolimy, wygnany Adam zszedł z powodu upadku grzechu, to znaczy opuścił to, co życiodajne dla słabego. Wygnanie jego natury (naturae suae) sprawiła nie zmiana miejsca, lecz przemiana obyczajów. Był bowiem bardzo odmienny od owego Adama, który się cieszył nienaruszalnym szczęściem, a gdy wpadł w grzechy tego świata, dostał się między zbójców. Nie wpadłby między nich, gdyby nie stał się winnym złamania boskiego nakazu. Kim są owi zbójcy, jeśli nie aniołami mocy i ciemności, którzy się niekiedy przemieniają w aniołów światłości, ale trwać w tym nie mogą? Ci najpierw obdzierają nas z szaty łaski duchowej, którą otrzymaliśmy, a potem zwykli nas ranić. Gdybyśmy zachowali nieskalane szaty, które otrzymaliśmy, nie czulibyśmy uderzeń zbójców. Strzeż się zatem, byś ogołocony jak niegdyś Adam, zaniedbawszy przestrzegania niebiańskiego nakazu i pozbawiony szaty wiary, nie otrzymał śmiertelnej rany: w nim (in quo) zostałby zabity cały rodzaj ludzki (omne genus humanum), gdyby ów schodzący Samarytanin nie opatrzył jego ciężkich ran" ${ }^{\prime 5}$.

Samo wyrażenie „ludzka natura” (natura, genus) zawiera w sobie ideę tajemniczej jedności między Adamem i wszystkimi ludźmi ${ }^{66}$. Grzech Adama był grzechem całego jego potomstwa, był w jakiś sposób grzechem natury.

${ }^{61}$ Ambrosius, Apologia altera prophetae David 12, 71, PL 14, 958, tłum. własne. Podobnie Ambroży mówi w Expositio Evangelii secundum Lucam VII 234, PL 15, 1762, tłum. własne: „Był Adam, a w nim byliśmy wszyscy; zginął Adam, a w nim wszyscy zginęli”.

${ }^{62}$ Por. Gross, Geschichte des Erbsündendogmas, I, s. 239.

${ }^{63}$ Por. A. Gaudel, Péché originel, DThC XII 366.

${ }^{64}$ Ambrosius, De excessu fratris sui Satyri 2, 6, PL 16, 1317, thum. własne.

${ }^{65}$ Tenże, Expositio Evangelii secundum Lucam VII 73, PL 15, 1718, thum. własne.

${ }^{66}$ Por. J. Mara, The Notion of Solidarity in Saint Ambrose's Teaching on Creation, Sin and Redemption, „Augustinianum” 18 (1978) 20. 
Jak thumaczy Josef Huhn, powszechność grzechu pierworodnego wynika dla Ambrożego z realnego włączenia wszystkich ludzi w Adama. Wszyscy ludzie zatem brali udział w grzechu Adama, bo wszyscy byli w nim zawarci ${ }^{67}$. Ambroży nigdzie nie podaje ontologicznego wyjaśnienia swoich - skądinąd bardzo znaczących - stwierdzeń. Jedyne, co można bezsprzecznie stwierdzić, to fakt solidarności ludzkości z Adamem.

Wskazałam powyżej najbardziej znaczące wypowiedzi Ojców o jedności czy solidarności ludzkości z Adamem. Nie da się wymieniać tu wszystkich, którzy mówili o winie Adama jako o „naszym grzechu”, twierdzili, że „my” obraziliśmy Boga w Adamie, uznawali, że „wszyscy” byliśmy w lędźwiach Adama, gdy popełniał grzech, wreszcie uznawali, że „wszyscy ludzie” zgrzeszyli w Adamie. To nie są wyjątkowe wypowiedzi, których trzeba szukać z lupą w pismach Ojców. Większość Ojców, a może nawet wszyscy byli przekonani o realnej jedności wszystkich ludzi, a jednym z wymiarów tej jedności był prawdziwy udział wszystkich ludzi w grzechu Adama.

Zresztą przeświadczenie o jedności całej ludzkości nie było wymysłem chrześcijaństwa. Wyrazem powszechnego przekonania o jedności ludzkości czy nawet całego świata są starożytne koncepcje filozoficzne, przede wszystkim neoplatonizm i stoicyzm. Oba te systemy bazują na przekonaniu o organicznej jedności wszystkiego - trudno mi sobie wyobrazić, że wzięły się znikąd. Wymyślili je ludzie, którzy na co dzień żyli zanurzeni w głębokim intuicyjnym przekonaniu o realnym związku wszystkiego ze wszystkim, o jedności świata, a więc także o jedności wszystkich ludzi. Potwierdzeniem powszechności takiego myślenia jest wyraźna, explicite wyrażona myśl o solidarności ludzkości w Adamie, zarówno u Ojców greckich, jak i łacińskich.

Badacze patrystycznej nauki o grzechu pierworodnym zgodnie uznają, że nauka ta była tak samo powszechna na Wschodzie jak i na Zachodzie. Frederick Robert Tennant stwierdza wręcz, że kluczowe idee teorii Augustyna zostały sformułowane na Wschodzie tak samo wcześnie jak na Zachodzie ${ }^{68}$. Stanislas Lyonnet zwraca uwagę na podobieństwo idei mimo różnorodności terminologicznej. Przypomina, że wiele klasycznych dzieł na temat grzechu pierworodnego sugeruje, iż tylko pisarze łacińscy uznawali grzech pierworodny, a Grecy mówili tylko o dziedziczonej śmierci. Sam zaznacza jednak, że wszystko zależy od sensu, jaki przypiszemy tym określeniom. U Ojców greckich słownictwo nie przypomina tego z Soboru Trydenckiego czy stosowanego przez Ojców łacińskich, ale doktryna wydaje się identyczna ${ }^{69}$.

${ }^{67}$ Por. J. Huhn, Ursprung und Wesen des Bösen und der Sunde: nach der Lehre des Kirchenvaters Ambrosius, Padeborn 1933, 133n.

${ }^{68}$ Por. Tennant, The Sources of the The Fall and Original Sin, s. 345.

${ }^{69}$ Por. Lyonnet, Le péché originel, s. 61. 
I rzeczywiście, jak zauważają Maurizio Flick i Zoltán Alszeghy, pisarze chrześcijańscy już w ciągu pierwszych trzech wieków dostrzegali, że ludzkość jest obarczona dziedziczonym zniszczeniem, przez które różni się od swojego stanu pierwotnego i które pochodzi od nieposłuszeństwa Adama, pociąga ludzkość do mnożenia grzechów i poddaje wiecznej śmierci. Jednak termin „grzech" był ogólnie rzecz biorąc zarezerwowany dla grzechów osobistych ${ }^{70}$. To samo przekonanie wyraża David L. Balás. Istnieje według niego szeroko rozpowszechniony pogląd, że Ojcowie Wschodni nie mówią o peccatum originale originatum (grzechu pierworodnym w nas). Jednak także w przedaugustyńskim nauczaniu Ojców Wschodnich znajdziemy przekonanie, że upadek pierwszego człowieka odłączył go od jedności z Bogiem i w jakiś sposób wszyscy ludzie w tym upadku uczestniczyli ${ }^{71}$. John Norman Davidson Kelly podkreśla, że Ojcowie greccy posiadają wielkie poczucie mistycznej jedności rodzaju ludzkiego z pierwszym człowiekiem. Jest to dawna doktryna rekapitulacji i na jej podstawie przyjmują bez zastrzeżeń, że nasz upadek zawierał się w upadku Adama. Skłonni są także patrzeć na grzech pierworodny jako na ranę zadaną naszej naturze ${ }^{72}$.

Koncepcja jedności ludzkości w Adamie nie stanowi alternatywy dla tradycyjnej katolickiej nauki o grzechu pierworodnym. Może być raczej jej dopełnieniem czy też wyjaśnieniem z innej perspektywy. Czy zatem Ojcowie przed Augustynem mówili o grzechu pierworodnym? Oczywiście nie! Nie znajdziemy u Ojców przed Augustynem terminu ,grzech pierworodny”. A jednak, Ojcowie przed Augustynem mówili o grzechu pierworodnym, bo ich pisma zawierają naukę, która w podstawowych założeniach zgadza się z późniejszym dogmatem. Owo podstawowe założenie to fakt, że Adam utracił świętość i sprawiedliwość nie tylko dla siebie, ale także dla nas; że przekazał całemu rodzajowi ludzkiemu nie tylko śmiertelność i cierpienia ciała, ale także grzech, to znaczy śmierć duszy ${ }^{73}$. Upadek pierwszego człowieka odłączył go od jedności z Bogiem i w jakiś sposób wszyscy ludzie w tym upadku uczestniczyli. A to właśnie stanowi istotę i sens grzechu pierworodnego.

\footnotetext{
${ }^{70}$ Por. M. Flick - Z. Alszeghy, Fondamenti di una antropologia teologica, Firenze 1970, 196.

${ }^{71}$ Por. D.L. Balás, Plenitudo Humanitatis: The Unity of Human Nature in the Thought of Gregory of Nyssa, w: Disciplina nostra: Essays in memory of Robert F. Evans, Cambridge 1979, 124.

${ }^{72}$ Por. J.N.D. Kelly, Początki doktryny chrześcijańskiej, tłum. J. Mrukówna, Warszawa 1988, 260.

${ }^{73}$ Por. E. McClear, The Fall of Man and Original Sin in the Theology of Gregory of Nyssa, ThS 9 (1948) 191; Vives, El pecado original en San Gregorio di Nisa, s. 190. Chociaż obaj pisali o Grzegorzu z Nyssy, ich twierdzenia świetnie pasują także do pozostałych Ojców.
} 


\section{DID THE FATHERS OF THE CHURCH BEFORE AUGUSTINE SPEAK ABOUT THE ORIGINAL SIN?}

\section{(Summary)}

It is true that the Fathers of the Church before Augustine did not use the term „original sin”. However, in the writings of very many of them, both in the East and in the West, we do find a belief in the solidarity of all people with Adam or even in the unity of entire humanity in Adam. Talking about the first sin the Fathers use the expression ,our" sin; they claim that ,we” offended God in Adam, they admit that ,we all" were in Adam's loins when he committed the sin, and finally they straightforwardly claim that ,all people” sinned in Adam. Some of them feel personally responsible for the offence committed in Paradise. Most of the Fathers, and perhaps even all of them, were convinced of real unity of entire humanity and they considered participation of all people in Adam's sin as one of the aspects of that unity. The fall of the first man separated not only himself, but also all people from the communion with God, because every man somehow participated in that fall. And that is, after all, the very essence of the original sin.

Słowa kluczowe: Adam, Ambrozjaster, Ambroży z Mediolanu, Dydym Ślepy, grzech pierworodny, Grzegorz z Nazjanzu, Grzegorz z Nyssy, Ireneusz z Lyonu, Metody z Olimpu, Ojcowie Kościoła, Orygenes, Tertulian.

Key words: Adam, Ambrosiaster, Ambrose of Milan, Didymus the Blind, original sin, Gregory of Nazianzus, Gregory of Nyssa, Irenaeus, Methodius of Olympus, Fathers of the Church, Origen, Tertullian. 
